
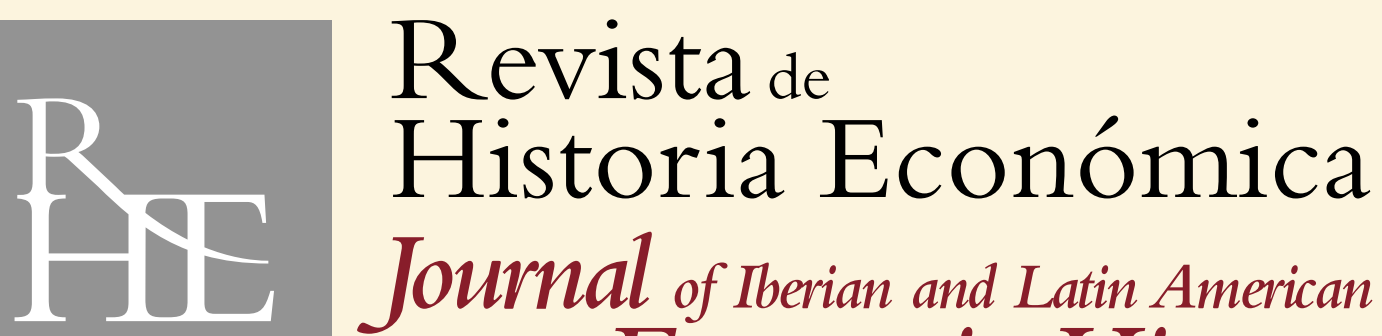
Journal of Iberian and Latin American
Economic History

vol. 34 • Issue 2 - September 2016

Panorama

Revisiting the legacy of colonialism

ALEJANDRA IRIGOIN

Revisiting the Legacy of Colonialism in Africa, India and Latin America:An Introduction ALEJANDRA IRIGOIN

Representation without Taxation, Taxation without Consent: The Legacy of Spanish Colonialism in America

\title{
TIRTHANKAR ROY
}

The British Empire and the Economic Development of India (1858-1947)

EWOUT FRANKEMA, ERIK GREEN AND ELLEN HILLBOM

Endogenous Processes of Colonial Settlement. The Success and Failure of European Settler Farming in Sub-Saharan Africa

Articles/Artículos

AGUSTINA VENCE CONTI AND EDUARDO MARTÍN CUESTA Precios y Salarios durante la crisis de 1890 en Buenos Aires

ENRIQUE LLOPIS AND FELIPA SÁNCHEZ

The Crisis of 1803-1805 in the Two Castiles: Foodstuff, Mortality and Institutional Collapse

JOSÉ M. MENUDO

Cartas españolas de Jean-Baptiste Say: Evidencias para el estudio de la circulación de ideas económicas

Published by

\section{CAMBRIDGE UNIVERSITY PRESS}




\section{Revista de Historia Económica}

\section{Journal of Iberian and Latin American Economic History}

EDITORS / DIRECTORES

Sandra Kuntz Ficker, El Colegio de México, México

Blanca Sánchez Alonso (Chief Editor),

Universidad CEU-San Pablo, Madrid, Spain

William Summerhill, UCLA, USA

EDITORIAL BOARD / CONSEJO EDITORIAL

Carlos Álvarez Nogal, Universidad Carlos III de Madrid, Spain

Renato P. Colistete, Universidade de São Paulo, Brasil

Antonio Cubel, Universidad de Valencia, Spain

José G. Díaz Bahamonde, Pontificia Universidad

Católica de Chile, Chile

Rafael Dobado, Universidad Complutense, Madrid, Spain

Mauricio Drelichman, University of British Columbia, Canada

Stanley Engerman, Rochester University, USA

Rui Pedro Esteves, Oxford University, UK

Pablo Gerchunoff, Universidad Torcuato di Tella, Argentina

Regina Grafe, European University Institute, Italy

Alfonso Herranz, Universitat de Barcelona, Spain

Alejandra Irigoin, London School of Economics, UK

Herbert S. Klein, Stanford University, USA

Pedro Lains, Instituto de Ciências Sociais, Lisboa, Portugal

Carlos Marichal, El Colegio de México, México

Graciela Márquez, El Colegio de México, México

Aldo Musacchio, Brandeis International Business School, USA

David Reher, Universidad Complutense, Madrid, Spain

James Robinson, Harvard University, USA

Joan Ramón Rosés, London School of Economics and Political Science, UK

Jeffrey G. Williamson, Harvard University, USA

BOARD OF TRUSTEES / PATRONATO

Luis Bértola, Universidad de la República, Uruguay Juan Carmona, Universidad Carlos III de Madrid, Spain Sebastián Coll, Universidad de Cantabria, Spain Alan Dye, Barnard College, Columbia University, USA

Pablo Martín Aceña, Universidad de Alcalá, Spain

Adolfo Meisel Roca, Banco de la República de Colombia

Benigno Pendás, Centro de Estudios Políticos y

Constitucionales, Spain

Antonio Tena, Universidad Carlos III de Madrid, Spain
RHE-JILAEH is published by Cambridge University Press for the Instituto Figuerola de Historia y Ciencias Sociales, Universidad Carlos III de Madrid

\section{SUBSCRIPTIONS}

RHE-JILAEH (ISSN 0212-6109) is published three times a year in March, September and December. The three parts form one annual volume. The 2016 subscription price for volume 34 , which includes print and electronic access, is $\mathcal{C}_{169.00}$ (US $\$ 274.00$ in USA, Canada and Mexico, €203.00 in Euro-zone Europe). The electronic-only price available to institutions is $£ 135.00$ (US $\$ 224.00$ in USA, Canada and Mexico, $€ 166.00$ in Euro-zone Europe). Individuals may purchase a print-only subscription at the reduced rate of $£ 46.00$ (US $\$ 76.00$ in USA, Canada and Mexico, $€ 55.00$ in Euro-zone Europe), ordering directly from the publisher and certifying that the journal is for their personal use. Single parts are priced at $£ 65.00$ (US $\$ 105.00$ in USA, Canada and Mexico, $€ 78.00$ in Euro-zone Europe) plus postage.

All prices include delivery, by air if appropriate, and excludeVAT. EU subscribers (outside the UK) who are not registered forVAT should add VAT at their country's rate.VAT registered members should provide their VAT registration number. Japanese prices for institutions (including ASP delivery) are available from Kinokuniya Company Ltd, P.O. Box 55, Chitose, Tokyo 156, Japan.

Orders, which must be accompanied by payment, may be sent to a bookseller, subscription agent or direct to the publisher: Cambridge University Press, Journals Fulfilment Department, UPH, Cambridge CB2 8BS; or in the USA, Canada and Mexico: Cambridge University Press, Journals Fulfillment Department, 32 Avenue of the Americas, New York, NY 10013, USA. Periodicals postage paid at New York, NY and at additional mailing offices.

\section{COPYING}

This journal is registered with the Copyright Clearance Center, 222 Rosewood Drive, Danvers, MA 01923, USA. Organizations in the USA who are also registered with the C.C.C. may, therefore copy material (beyond the limits permitted by, sections 107 and 108 of U.S. Copyright law) subject to payment to the C.C.C of the per copy fee of $\$ 15.00$. This consent does not extend to a multiple copying for promotional or commercial purposes. Code 0212-6109/16. ISI Tear Sheet Service, 3501 Market Street, Philadelphia, PA 19104 , USA, is authorized to supply single copies of separate articles for private use only. Organizations authorized by the Copyright Licensing Agency may also copy, material subject to the usual conditions. For all other use, permission should be sought from Cambridge or from the American Branch of Cambridge University Press.

RHE-JILAEH is included in the Cambridge Journals Online journals service which can be found at http://journals.cambridge.org/rhe

CInstituto Figuerola de Historia y Ciencias Sociales, Universidad Carlos III de Madrid, 2016

ISSN 0212-6109 E-ISSN 2041-3335

This journal issue has been printed on FSC-certified paper and cover board. FSC is an independent, non-governmental, not-forprofit organization established to promote the responsible management of the world's forests. Please see www.fsc.org for information. 


\section{CONTENTS / SUMARIO}

\section{Panorama}

\section{Revisiting the legacy of colonialism}

163 Alejandra Irigoin

Revisiting the Legacy of Colonialism in Africa, India and Latin America:

An Introduction

169 Alejandra Irigoin

Representation without Taxation, Taxation without Consent: The Legacy of Spanish Colonialism in America

209 Tirthankar Roy

The British Empire and the Economic Development of India (1858-1947)

237 Ewout Frankema, Erik Green and Ellen Hillbom

Endogenous Processes of Colonial Settlement. The Success and Failure of European Settler Farming in Sub-Saharan Africa

\section{Articles/Artículos}

267 Agustina Vence Conti and Eduardo Martín Cuesta Precios y Salarios durante la crisis de 1890 en Buenos Aires

295 Enrique Llopis and Felipa Sánchez The Crisis of 1803-1805 in the Two Castiles: Foodstuff, Mortality and Institutional Collapse

323 José M. Menudo

Cartas españolas de Jean-Baptiste Say: Evidencias para el estudio de la circulación de ideas económicas 